\title{
Kegiatan Awal Masyarakat Tionghoa di Indonesia
}

Salah satu tuduhan yang sering dilontarkan terhadap golongan etnis Tionghoa di Indonesia adalah sifat mereka yang cenderung eksklusif. Tudingan itu ada benarnya, walaupun itu merupakan salah satu faktor dari sikap stereotyping yang umum dianut suatu golongan mayoritas terhadap golongan minoritas tertentu. Eksklusivisme di kalangan minoritas Tionghoa di Indonesia muncul bukan saja karena mereka memang golongan minoritas dan keturunan emigran, tetapi juga karena sejarah perkembangan masyarakat mereka yang berbeda dengan sejarah masyarakat pribumi, khususnya dalam berinteraksi dengan pemerintah penjajahan Belanda pada masa kolonial.

Tulisan ini mencoba mencari akar sejarah dari eksklusivisme yang sering dituduhkan tersebut dengan menelusuri evolusi perkembangan masyarakat etnik Tionghoa sejak kedatangan mereka di Indonesia sampai pada waktu kira-kira ketika kesadaran nasionalisme Indonesia mulai muncul. Penulis berasumsi bahwa perlakuan pemerintah Hindia Belanda dan munculnya nasionalisme Cina di Daratan Cina sangat berpengaruh pada perkembangan ekonomi, sosial, dan politik di kalangan mereka. Karena itulah ketika kesadaran nasionalisme Indonesia muncul, masyarakat Tionghoa tidak banyak terpengaruh, dan sebagian besar golongan etnik Tionghoa kurang tertarik terhadapnya. Sementara itu ketika nasionalisme Indonesia muncul, nasionalisme Cina sudah lama bersemi di kalangan masyarakat etnik Tionghoa di Indonesia.

\section{KEDATANGAN ORANG-ORANG TIONGHOA DI INDONESIA}

Terdapat banyak bukti sejarah bahwa pedagang-pedagang Tionghoa telah datang ke daerah-daerah pesisir Laut Cina Selatan (orang Cina menyebutnya Nanyang) sejak 300 tahun sebelum Masehi. Namun catatan-catatan sejarah tertulis menunjukkan mereka telah datang ke Asia Tenggara sebagai pedagang lama setelah itu. Sekitar abad ke-11, mereka datang ke negaranegara di Asia Tenggara yang terletak di daratan Asia sebagai pedagang. 
Pada awalnya mereka hanya tinggal untuk jangka waktu yang pendek selama masa kunjungan perdagangan mereka di beberapa kota pesisir (Wang Gung Wu 1959: 2-3). Bagaimana mereka menjadi penduduk tetap di Indonesia dan bagaima-na proses tersebut berlangsung belum ada gambaran yang jelas. Akan tetapi, lama sebelum Jayakarta dikuasai oleh Belanda di bawah pimpinan Jan Pieterszoon Coen pada tahun 1619 yang kemudian mengubah namanya menjadi Batavia (sekarang Jakarta), orang-orang Tionghoa telah menetap di wilayah yang sekarang Banten dan tempat-tempat lain di luar Jawa (Purcell 1965: 391).

Pada masa penyerangan Kompeni terhadap Jakarta, orang-orang Tionghoa dipekerjakan sebagai perantara dalam pengaturan kapitulasi beberapa kalangan ningrat setempat kepada Belanda. Ketika Coen menjadi gubernur jendral di Batavia, ia mengizinkan sekitar 350 orang Tionghoa untuk tinggal di dalam kota dan dipekerjakan sebagai pedagang kecil (Purcell 1965: 395). Coen ingin membuat Batavia berkembang secepat mungkin sebagai kota perdagangan terbesar di seluruh Hindia Belanda. Untuk mewujudkan citacita itu, ia secara khusus mendukung pemberian izin menetap bagi orang Tionghoa untuk bergerak di bidang pedagangan, industri dan pertanian. Sejak saat itu, kedatangan imigran Tionghoa ke Batavia secara berangsur-angsur meningkat. Pada tahun 1629, terdapat sekitar 2000 orang Tionghoa di Batavia dan pada tahun 1725 telah mencapai 10.000 orang (Purcell 1965: 397).

Jumlah masyarakat Tionghoa di Hindia Belanda meningkat pesat pada pertengahan abad ke-19, ketika ekonomi koloni meningkat sebagai akibat diperkenalkannya Sistem Tanam Paksa (Cultuurstelsel), pengembangan perkebunan dan pertanian di Sumatera, Kalimantan dan Sulawesi, serta penambangan timah di Bangka dan Belitung (Wang Gung Wu 1959: 23-4). Selain itu, peningkatan jumlah masyarakat Tionghoa yang datang ke Indonesia tidak hanya disebabkan oleh perkembangan ekonomi Hindia Belanda tetapi juga sebagai akibat dari perkembangan internal di Cina sendiri.

Dapat dikatakan terdapat dua faktor yang mendorong kedatangan kaum Tionghoa perantauan (huaqino) ke Hindia Belanda. Yang pertama adalah alasan ekonomi. Cina pada akhir abad ke-19 mengalami masalah ledakan penduduk. Proses ini dimulai sejak pertengahan abad ke-19 dan membawa pengaruh pada peningkatan angka kemiskinan, kerusuhan dan keresahan sosial. Hal itu kemudian menyebabkan terjadinya proses pelemahan fondasi sistem kekaisaran Cina. Kecenderungan diperburuk lagi oleh terjadinya bencana alam seperti banjir, kekeringan, wabah dan sebagainya yang selalu menghantui rakyat Cina sepanjang sejarah negeri itu (Houn 1973: 1-2). 
Migrasi besar-besaran dari Cina setelah tahun 1850 lebih dipacu oleh kemunduran fondasi ekonomi Cina sendiri. Sejak awal abad ke-19, Kekaisaran Cina berada dalam proses kehancuran yang disebabkan oleh campurtangan imperialisme Barat (Wang Gung Wu 1959: 25). Kondisi dalam negeri Cina yang tidak menguntungkan itu menyebabkan banyak orang Tionghoa meninggalkan kampung halaman mereka. Tak sedikit di antara mereka yang mencoba mengadu untung ke luar negeri, terutama ke berbagai negara yang mengalami kekurangan penduduk di Asia Tenggara serta memiliki kondisi dan prospek ekonomi dan kekayaan alam yang lebih baik. Alasan kedua adalah alasan politik. Banyak patriot Cina yang mengalami kekecewaan oleh pergantian kekuasaan dari Dinasti Ming (1368-1644) ke Dinasti Qing (16441911). Dinasti Qing, yang didirikan oleh suku Manchu dianggap sebagai dominasi Cina oleh bangsa asing. Oleh karena itu, banyak orang Tionghoa meninggalkan negerinya, dan wilayah yang menjadi pilihannya adalah negara-negara di selatan. Selain alasan ekonomi, rintangan alam tampaknya juga menjadi alasan mengapa mereka pergi ke selatan. Perjalanan ke selatan ditempuh melalui Lautan Pasifik, sedangkan wilayah utara dan barat hanya terdiri dari wilayah-wilayah yang tidak atau kurang menarik bagi mereka seperti Siberia, Himalaya dan India.

Orang-orang Tionghoa yang datang ke Indonesia sebagian besar berasal dari provinsi-provinsi selatan seperti Guangdong, Fujian dan Guangxi (Purcell 1965: 24). Oleh karena itu, kelompok terbesar masyarakat Cina perantauan di Asia Tenggara adalah suku-suku Hokkian, Teochiu, Kanton, Hakka dan Hainan (Heidhues 1974: 4). Dapat dikatakan, kelompok-kelompok Tionghoa Perantauan ini memiliki kecenderungan untuk memper-tahankan kepercayaan religi dan kebudayaan mereka. Konfusianisme, Budhisme dan Taoisme tetap menjadi acuan hidup mereka meskipun ada di kalangan mereka yang memeluk agama Islam (Purcell 1965: 413).

Posisi masyarakat Tionghoa meningkat dari buruh kasar dan pedagang kecil menjadi pekerja terdidik ketika pemerintah kolonial Belanda memanfaatkan mereka sebagai pemungut pajak (Day 1966: 361). Di masa-masa berikutnya, ketika mereka kehilangan status sebagai pemungut pajak, posisi mereka dalam kegiatan bisnis telah mengakar. Pedagang Eropa sangat iri akan status masyarakat Tionghoa sebagai kelas pedagang, namun mereka tidak dapat melakukan hubungan bisnis tanpa bekerja sama dengan masyarakat Cina terutama dalam melaksanakan transaksi dengan penduduk asli. Gagasan untuk menyingkirkan mereka dari aktivitas bisnis di tanah jajahan merupakan sesuatu yang kuno, terutama dalam sejarah Jawa, namun, 
menurut Clive Day, "Orang Tionghoa adalah misionaris organisasi ekonomi modern bagi penduduk setempat" (Day 1966: 362, 365).

\section{KOMUNITAS TIONGHOA DI INDONESIA}

Komunitas Tionghoa Perantauan di Indonesia pada akhir abad ke-19 masih belum bersatu. Provinsialisme, perbedaan bahasa dan budaya di kalangan mereka masih sangat besar. Hal itu diperburuk dengan tersebarnya mereka di berbagai wilayah di Indonesia. Kecenderungan itu tampaknya memiliki persamaan dengan situasi di negeri Cina sendiri. Dr. Sun Yat-sen, bapak pendiri Republik Cina, menggambarkan negeri dan bangsa Cina yang didasarkan pada sistem keterikatan keluarga, desa dan lokasi pemukiman mereka pada saat itu tak bedanya dengan "segenggam pasir" yang kalau dilepas akan tercerai berai (Sun Yat-sen, t.t.: 31 ).

Setelah akhir abad ke-19, ketika makin banyak imigran Tionghoa yang datang ke Indonesia, terdapat perbedaan antara Tionghoa Peranakan dan Tionghoa Totok. Sebelum akhir abad ke-19, masyarakat Cina yang datang ke Indonesia didominasi oleh kaum pria karena mereka meninggalkan keluarga atau istri mereka di Cina. Mereka mengawini wanita setempat dan menyebabkan adanya percampuran antara kebudayaan Cina dan kebudayaan lokal. Mereka berbicara bahasa Melayu dan telah lupa akan bahasa mereka sendiri. Meskipun mereka menganut dan berhubungan dengan budaya dan masyarakat lokal, kendala budaya, ekonomi, lingkungan hidup, dan religi, menyebabkan mereka tetap terpisah dari komunitas lokal (Suryadinata 1978: $86-7)$. Mereka yang datang ke Indonesia lebih awal dari golongan itu disebut Tionghoa Peranakan. Golongan Totok adalah orang-orang Tionghoa yang datang ke Indonesia lebih kemudian. Pada pergantian abad, komunikasi antara Cina dengan dunia luar relatif menjadi lebih mudah dibandingkan dengan masa-masa sebelumnya. Oleh karena itu, mereka yang datang kemudian dapat membawa keluarga mereka dan ketika tiba di Indonesia, mereka secara penuh menjadi suatu kelompok eksklusif dalam masyarakat Indonesia. Mereka menggunakan bahasa daerah asal mereka di Cina dalam kalangan mereka dan pengetahuan mereka dalam bahasa setempat sangatlah terbatas. Mereka juga melakukan perkawinan di kalangan komunitas mereka sendiri. Masyarakat Tionghoa Totok lebih memiliki kesadaran sebagai orang Cina daripada kaum Peranakan (Suryadinata 1978: 90-1). Kesimpulannya, golongan Totok bisa disebut sebagai "kelewat Cina untuk disebut sebagai orang orang Indonesia," sedangkan golongan Peranakan "kelewat Indonesia untuk disebut orang Cina." Dalam istilah sosiologis kedua golongan itu bisa dikategorikan sebagai golongan marginal. 
Perbedaan orientasi budaya antara kedua golongan tersebut telah menimbulkan pertentangan. Banyak usaha yang telah dijalankan untuk mempersatukan kedua pihak, akan tetapi semua usaha tersebut gagal karena perbedaan kultural di antara kedua golongan itu sangat besar (Suryadinata 1978: 94). Tulisan ini tidak membahas tentang konflik antara Tionghoa Totok dan Peranakan karena keduanya sedikit banyak telah mendapat pengaruh nasionalisme bangsa Cina. Karena itu tidak terdapat suatu konflik yang jelas antara Tionghoa Peranakan dan Tionghoa Totok dalam masalah nasionalisme bangsa Cina, meskipun harus diingat bahwa kelompok Totok tentu saja mendapat lebih banyak pengaruh dari nasionalisme Cina daripada kaum Peranakan.

Pada dimensi lain, meskipun masyarakat Tionghoa terpecah belah, mereka juga terpisah dengan masyarakat lokal karena perbedaan yang mendalam dengan komunitas pribumi. Hal itu disebabkan oleh beberapa faktor. Masyarakat Indonesia asli sebagian besar adalah masyarakat muslim. Tidaklah mudah bagi kaum muslim untuk hidup berdampingan secara harmonis dengan kaum Cina "pemakan babi". Pada waktu itu tentu saja telah ada kaum Tionghoa Muslim, namun jumlah mereka masih sangat kecil. Faktor lainnya adalah rintangan kultural. Kebudayaan lokal Indonesia menerima pengaruh India dan Islam, sedangkan masyarakat Cina memiliki latar belakang kebudayaan yang sangat berbeda. Masyarakat Tionghoa dikenal dengan chauvinisme kebudayaan mereka yang tebal dan selalu memandang rendah kebudayaan lain di luar kebudayaan Cina. Kesadaran itu sampai saat ini masih menjadi salah satu batu sandungan dalam proses asimilasi mereka dengan kebudayaan dan masyarakat Asia Tenggara. Faktor ekonomi juga memiliki peranan penting. Sebagian besar masyarakat asli Indonesia hidup dari pertanian sehingga kebanyakan dari mereka hidup di pedesaan. Di lain pihak, hampir semua anggota masyarakat Cina hidup di daerah perkotaan dan menggantungkan diri dan hidupnya dari perdagangan dan perburuhan. Faktor ekononi menjadi penentu dalam pola hubungan antara masyarakat Indonesia lokal dengan masyarakat Cina. Setelah Belanda mempekerjakan masyarakat Cina sebagai medium antara pemerintah kolonial dengan masyarakat Indonesia dan karena orang-orang Cina mendominasi perdagangan dan perekonomian yang disebabkan oleh sifat hemat dan kemampuan bisnis mereka, faktor ekonomi menjadi sumber ketegangan utama antara masyarakat lokal dengan orang-orang Cina pada tahun-tahun berikutnya.

Sejak pertengahan abad ke-19, pada waktu liberalisasi perekonomian di Hindia Belanda diperkenalkan setelah penghapusan Sistem Tanam Paksa, 
para penguasa Belanda membuka kesempatan perekonomian, terutama bisnis perkebunan di Jawa dan Sumatera serta pertambangan di kepulauan Malaka. Untuk memenuhi kebutuhan akan tenaga kerja, mereka mendatangkan kaum buruh dari tempat-tempat lain, terutama orang-orang Cina. Di satu pihak, orang-orang Cina yang meninggalkan negerinya tersebut berada dalam posisi yang sulit. Sampai tahun 1894, pemerintah Imperial di Cina menganggap mereka sebagai kaum pembangkang dan oleh karena itu kepergian mereka meninggalkan Cina dianggap illegal (Willmott 1961: 2). Namun, beban politik dan ekonomi dalam negeri Cina, ditambah pesona perkembangan perekonomian di Hindia Belanda menyebabkan lebih banyak lagi orang-orang Cina yang datang ke Indonesia. Jelas terlihat bahwa karena orang-orang Cina tersebut adalah buruh, mereka berasal dari strata bawah masyarakat Cina. Posisi mereka sebagai mediator antara pemerintah kolonial dan masyarakat lokal dan kemudian keikutsertaan mereka dalam perdagangan kecil hanya terjadi pada masa-masa berikutnya. Keikutsertaan masyarakat Cina dalam masalah usaha dan perdagangan didorong oleh orang Belanda. Perkembangan perekonomian Indonesia di berbagai bidang membutuhkan jumlah tenaga kerja yang tidak mungkin dipenuhi oleh bangsa Belanda. Oleh karena itu, orang-orang Cina diizinkan dan didorong untuk berpartisipasi dalam bidang usaha dan jaringan finansial dari daerah pedesaan sampai pelabuhan utama. Dalam tahun-tahun selanjutnya bahkan terdapat lebih banyak lagi orangorang Cina perantauan yang dipekerjakan oleh orang-orang Belanda sebagai mandor atau pekerja kerah putih dalam perusahaan-perusahaan Belanda (Skinner 1967: 98).

Dari pembahasan tersebut dapat dilihat bahwa pada awalnya pemerintah kolonial Belanda membutuhkan orang-orang Cina untuk memenuhi kekurangan tenaga kerja dalam era tinggal landas ekonomi mereka, namun ketika semakin banyak masyarakat Cina yang memasuki koloni dan menyebabkan berbagai masalah sosial seperti kejahatan dan pengangguran, pemerintah kolonial mengambil beberapa tindakan untuk menghambat pergerakan masyarakat Cina. Pada 1900, meskipun orang-orang Cina telah mengembangkan status ekonomi mereka, pemerintah Belanda tetap menghambat perdagangan dan gerakan mereka. Peraturan pemukiman memaksa orang-orang Cina untuk tinggal dalam lokasi yang dikhususkan bagi mereka di kota-kota besar. Untuk setiap perjalanan ke pedesaan dalam rangka bisnis atau perdagangan, orang-orang Cina harus memiliki izin dari penguasa Belanda (Purcell 1965: 439). Posisi legal mereka juga menyerupai masyarakat lokal dan oleh karena itu dianggap lebih rendah dari orang Eropa 
pada umumnya, walaupun dalam tatanan masyarakat mereka dimasukkan ke dalam kategori "Timur Asing" (Vreemde Oosterlingen) (Purcell 1965: 436).

Sementara itu, sebagai mediator antara komunitas Cina yang terus meningkat dan administrasi kolonial, orang-orang Belanda memperkenalkan "sistem opsir" yang terutama berkembang di Jawa. Dalam sistem ini, pemerintah kolonial Belanda menunjuk orang-orang tertentu yang memiliki pengaruh dalam komunitas Cina untuk menjadi pimpinan atau kepala komunitas Cina. Hal itu, menurut pemerintah kolonial berdasarkan pada prinsip bahwa setiap orang memiliki pemimpinnya sendiri. Furnivall, seorang sejarawan dan ahli sosiologi terkemuka, mengatakan bahwa Belanda mengikuti sistem oriental yang dipraktekkan di Malaka ketika Malaka menjadi pusat perdagangan di Asia Tenggara dan dilanjutkan oleh Portugis yang mengambil alih pelabuhan pada abad ke-15 (Furnivall dikutip oleh Coppel 1976: 22). Namun, menurut Charles Coppel, pernyataan Furnivall itu dapat menyesatkan jika diinterpretasikan bahwa masyarakat Cina bersifat independen atau tidak memiliki otonomi dibawah pemimpin mereka. Pada kenyataannya, komunitas Cina tidak memilih pemimpin sebagai wakil mereka tetapi justru pemerintah kolonial-lah yang menunjuk dan menyeleksi calon pimpinan Cina tersebut. Kriteria seleksi hampir seluruhnya didasarkan kepada kekayaan, kekuasaan dan hubungan bisnis dengan para pejabat Belanda (Coppel 1976: 22-3). Dengan kata lain penunjukkan para opsir tersebut sangat berwarna kolutif. Pada umumnya para opsir Cina itu tidak lebih dari alat pemerintah kolonial Belanda dan mewakili kepentingan pemerintah kolonial yang seringkali bertentangan dengan aspirasi komunitas Cina.

Kebijakan Belanda yang sewenang-wenang dalam membuat peraturanperaturan yang diterapkan pada masyarakat Tionghoa menyebabkan timbulnya rasa tidak puas di kalangan para anggota komunitas Cina tersebut. Mereka mulai menyadari bahwa persatuan di kalangan mereka tanpa memandang latar belakang suku dan asal-usul akan berguna dalam usaha mereka untuk memperoleh hak-hak dan status yang lebih baik dalam sistem administrasi kolonial. Rasa kesadaran itu berkembang pada saat yang sama dengan pemunculan gerakan politik di dalam negeri Cina, yang kemudian lebih dikenal sebagai gerakan nasionalisme dan modernisasi.

\section{PENGARUH NASIONALISME DAN MODERNISASI DI CINA TERHADAP MASYARAKAT CINA DI INDONESIA}

Nasionalisme di kalangan masyarakat Tionghoa di Indonesia muncul pada masa pergantian abad ke-20 sebagai akibat dari dua faktor. Pemerintah 
Hindia Belanda mengeluarkan berbagai peraturan yang membatasi aktivitas orang-orang Cina baik di bidang perdagangan maupun di bidang perburuhan. Pada 1890 hak untuk menjual opium diambil dari bangsa Cina dan kemudian dijadikan monopoli pemerintah. Masyarakat Cina kemudian menjadi semakin tidak puas ketika pada tahun yang sama pemerintah kolonial menerapkan Bank Kredit Pertanian untuk menolong petani. Sistem baru itu menyelamatkan masyarakat pedesaan dari lintah darat dan rentenir di pedesaan, namun pada sisi lain kebijakan baru itu telah menghancurkan usaha keuangan masyarakat Cina karena sebagian besar dari para rentenir terdiri dari orang-orang Tionghoa (Purcell 1965: 444-5).

Pendidikan adalah salah satu klausal dalam "Politik Etik," yakni suatu kebijakan baru yang diperkenalkan untuk meningkatkan kehidupan sosial kaum pribumi Indonesia. Namun kebijakan baru itu hanya memberikan lebih banyak kesempatan bagi penduduk setempat untuk mendapat pendidikan. Pendidikan untuk masyarakat Tionghoa tidak dimasukkan dalam kebijakan baru tersebut, meskipun mereka merasa bahwa mereka adalah pembayar pajak yang tertinggi dan punya saham yang tinggi dalam menaikkan pendapatan pemerintah kolonial. Hal itu juga telah menimbulkan perasaan tidak puas (Willmott 1961: 5). Sebagian besar anak-anak Cina pada waktu itu tidak bersekolah, namun mereka mendapat pendidikan di rumah dari guruguru privat. Dalam area yang memberlakukan hukum, orang-orang Cina lebih merasa tidak puas karena hukum Hindia Belanda membuat perbedaan dalam masalah hukum antara orang-orang Eropa, masyarakat oriental dan penduduk setempat. Orang-orang Eropa tentu saja menduduki posisi tertinggi, namun pada 1899 pemerintah kolonial memberlakukan kebijaksanaan yang memutuskan bahwa orang-orang Jepang, yang tergolong masyarakat oriental, memperoleh status yang sama dalam hukum dengan orang-orang Eropa. Keputusan itu tampaknya memukul orang-orang Cina dan menyebabkan timbulnya kecemburuan sosial (Willmott 1961:3).

Faktor lainnya adalah pengaruh pergerakan modernisasi dan revolusi dalam negeri Cina sendiri. Sejak dikalahkan dalam Perang Candu pada pertengahan abad ke-19, Cina telah menjadi sasaran persaingan pengaruh dan hak-hak istimewa di kalangan negara-negara imperialis Eropa dan Jepang sehingga Cina yang sedang dalam proses pelemahan dalam segala segi juga harus menderita karena penggerogotan yang datang dari luar. Puncak kelemahan Cina adalah kekalahannya dalam perang melawan Jepang pada 1895. Kekaisaran raksasa Cina yang selalu mengagungkan diri sebagai kekuatan besar ternyata dapat dikalahkan oleh negara kecil yang selalu dianggap jauh lebih inferior ketimbang Cina. Kejadian itu telah menyebabkan 
banyak kaum intelektual Cina mengalami disilusi dan merebaknya gagasangagasan revolusioner, reformasi dan modernisasi di kalangan mereka. Akan tetapi, pada waktu itu kekaisaran Cina masih berkuasa dan berakar dengan kuat sehingga gerakan modernisasi tersebut mengalami kegagalan. Banyak pemimpin reformasi dan revolusi yang ditangkap dan dihukum mati. Namun, banyak pemimpin gerakan pembaruan itu berhasil melarikan diri dan mencari perlindungan di luar Cina.

Tema-tema yang disebarluaskan para pemuka reformis seperti Kang Yuwei dan Liang Qichao adalah persatuan bangsa dan meningkatkan pengetahuan dan teknologi. Namun terdapat hal-hal baru dalam program kaum reformis yaitu untuk pertama kalinya dalam sejarah Cina, Kang dan Liang mengarahkan gagasan-gagasan mereka kepada masyarakat Cina perantauan. Tambahan lagi, Kang melihat sukses kaum Cina perantauan di luar negeri sebagai contoh dalam program untuk menjadikan Cina sebagai negara modern. Itu menyebabkan banyak kalangan generasi muda orangorang Cina di perantauan, tertarik pada program-program yang dikemukakan oleh kaum reformis (Yen Ching Hwang 1976: 54). Kang menjadi buronan politik dan memilih tinggal di Jepang. Dengan kehadirannya di luar negeri masyarakat Cina perantauan menjadi obyek langsung dari gagasangagasan politiknya. Pada 1903 ia datang ke Jawa dan mengunjungi beberapa sekolah yang telah didirikan di beberapa kota di Jawa. Ia menganjurkan agar kaum Cina perantauan di manapun mereka berada mempunyai pandangan politik dan budaya yang berorientasi kepada Cina (Willmott 1961: 5).

Kaum revolusioner muncul di antara kaum Cina perantauan setelah lenyapnya ide reformasi. Dr. Sun Yat-sen muncul dan memperkenalkan San Min Zhu Yi. Ia berpidato mengenai nasionalisme dan revolusi untuk menggulingkan pemerintahan Qing di Cina. Kaum Cina perantauan kelihatannya menjadi pendukung pertama Sun Yat-sen karena ia memulai pergerakan politiknya diantara komunitas Cina di luar negeri. Dr. Sun selalu menganggap kaum Cina perantauan memiliki peranan penting dalam aktivitasnya dan ia selalu membutuhkan dukungan mereka. Sikap ini cukup konsisten sepanjang karirnya sebagai pemimpin masyarakat Cina (Yen Ching Hwang 1976: 83). Selain itu, Dr. Sun Yat-sen juga melihat bahwa para pedagang kaya memiliki pengaruh yang besar dalam komunitas Cina di luar Cina. Karena itu untuk menghimpun dana buat membiayai aktivitas revolusionernya, Sun Yat-sen menjalin hubungan dengan orang-orang Cina kaya tersebut (Yen Ching Huang 1976: 93).

Sebagai akibat dari krisis ekonomi, politik, dan sosial di Cina sendiri, perasaan "solidaritas ke-Cina-an" mulai tumbuh dalam komunitas Cina di 
luar Cina, termasuk di Indonesia. Sejak saat itu mulai bermunculan pula minat terhadap Konfusianisme, sejarah Cina, kebudayaan Cina dan perkembangan keadaan di daratan Cina. Perasaan itu mengacu kepada keinginan untuk mempersatukan seluruh orang Tionghoa di Hindia Belanda sebagai suatu masyarakat yang kuat dan yang aspirasinya didengar oleh pemerintah kolonial. Selain itu, terdapat usaha dan gerakan untuk meningkatkan studi bahasa Cina meskipun banyak diantara mereka yang tidak dapat berbahasa Cina sama sekali. Pengajaran bahasa Cina di sekolah-sekolah yang mulai merebak sejak tahun 1900 adalah salah satu mekanisme propaganda untuk mempersatukan masyarakat Cina di tanah kolonial (Coppel 1976: 26).

Ketika melihat bagaimana pengaruh kaum reformis dan revolusioner pada masyarakat Cina yang tinggal di luar negeri, pemerintah Kekaisaran Cina di Beijing segera mengubah sikap dan kebijakannya dengan mencoba merangkul mereka. Pertimbangan ekonomi dan finansial kelihatannya sangat melatarbelakangi langkah pendekatan tersebut. Menurut Edgar Wickberg, beberapa gubernur Cina di provinsi-provinsi selatan, terutama Zhang Zhidong, beranggapan bahwa kaum Cina perantauan akan memainkan peran sangat aktif dalam modernisasi Cina dengan memberi sumbangan pada pembangunan ekonomi (Wickberg dikutip oleh Heidhues 1974: 87-8). Pemerintah Cina mengambil langkah lebih lanjut untuk memperkuat ikatan ekonomi, politik dan budaya antara masyarakat Cina di Daratan Cina dengan masyaratakat Cina perantauan. Untuk itu, pada tahun 1907, 1909 dan 1911 armada kapal Cina dikirim dari Cina untuk mengunjungi Batavia, Semarang dan Surabaya. Di seluruh tempat, kapal-kapal tersebut memperoleh sambutan yang hangat dari komunitas Cina setempat (Wllmott 1961: 5).

\section{AKTIVITAS MASYARAKAT CINA INDONESIA}

Sebagai akibat dari faktor yang telah dipaparkan, tahun-tahun pertama abad ke-20 merupakan awal perubahan besar-besaran dalam masyarakat Cina di Indonesia. Perasaan sebagai bagian dari negara Cina merupakan isu populer pada saat itu. Perasaan "Solidaritas Cina" terwujud dalam aktivitas ekonomi dan perdagangan, pergerakan untuk penyebaran pendidikan dan aktivitasaktivitas politik

\section{Gerakan Memajukan Pendidikan}

Pada awal 1900, ketika masyarakat Tionghoa perantauan mendengar untuk pertama kalinya mengenai pergerakan reformasi Liang Qichao dang Kang Youwei, beberapa tokoh golongan Tionghoa terdidik di Batavia mulai menyadari bahwa masyarakat Tionghoa setempat membutuhkan bimbingan 
moral yang "murni Cina" yang dapat digunakan sebagai sumber perkembangan dalam kehidupan sosial mereka. Kesadaran itu muncul setelah para pemuka masyarakat Tionghoa itu melihat adanya kebingungan pada masyarakat Tionghoa lokal dalam mempraktekkan dan mengerti tentang kebudayaan dan tradisi. Hubungan kebudayaan antara masyarakat Indonesia setempat dan kaum Cina perantauan menyebabkan munculnya kebudayaan campuran dalam komunitas Cina yang semakin lama semakin jauh dari kebudayaan dan tradisi Cina yang sesungguhnya. Oleh karena itu, orangorang yang memiliki kesadaran ini mengambil kesimpulan bahwa kebudayaan "murni Cina" harus dibangkitkan kembali. Orang-orang ini berhimpun dan membentuk asosiasi yang disebut Tiong Hoa Hrvee Koan (THHK). Asosiasi ini berfungsi sebagai pusat pergerakan untuk reformasi dan perkembangan kebudayaan dan tradisi Cina (Kwee Tek-hoay 1969: 11-2). Nio Joe Lan, seorang penulis Peranakan yang produktif dan terkemuka, mengatakan tujuan utama THHK adalah untuk memajukan dan mempersatukan masyarakat Tionghoa di Hindia Belanda dengan berdasarkan pada prinsip-prinsip Konfusianisme (Nio Joe Lan, t.t.: 7).

Oleh karena itu jelaslah bahwa sejak awal perhatian utama THHK sama sekali bukanlah bidang pendidikan, namun lebih kepada peningkatan kesadaran akan Konfusianisme di kalangan orang-orang Tionghoa yang tinggal di Indonesia. Gagasan pendirian sekolah Tionghoa muncul kemudian, ketika beberapa orang di antara para pendiri THHK sampai kepada pikiran jika THHK memiliki sarana pendidikan, itu dapat digunakan sebagai alat untuk memaksa pemerintah kolonial supaya memperhatikan pendidikan bagi masyarakat Cina yang sampai saat itu masih diabaikan (Kwee Tek-hoay 1969: 17).

Pada awalnya muncul beberapa perdebatan di kalangan pimpinan THHK. Beberapa anggota dewan merasa bahwa usaha untuk memberikan anak-anak Tionghoa di Indonesia suatu materi pendidikan yang berorientasi Cina adalah sia-sia. Untuk mendorong orang-orang Cina memperoleh status sama dengan orang Belanda, mereka harus memberikan pendidikan Belanda kepada anak-anak mereka. Namun saat itu, sangatlah sulit untuk masuk sekolah Belanda karena harus melewati jalan birokrasi yang panjang dan berbelit. Seorang anak keturunan Tionghoa baru dapat diterima dalam sekolah Eropa jika orang tuanya bersahabat dengan residen setempat atau asisten residen yang umumnya merangkap juga sebagai kepala dewan lokal sekolah Eropa. Kalaupun diterima, ia harus lancar berbahasa Belanda. Untuk itu ia harus mengikuti pendidikan khusus yang biayanya sangat tinggi, ditambah dengan kenyataan biaya pendidikan di sekolah Eropa umumnya 
sangat mahal sehingga tentu saja hanya anak-anak dari keluarga yang sangat kaya dan berpengaruh yang dapat bersekolah di sana. Akhirnya para pimpinan THHK setuju bahwa hanya terdapat satu jalan yaitu orang-orang Tionghoa harus menunjukkan minat mereka pada dunia pendidikan. Apabila itu masih tidak diperhatikan pemerintah kolonial, mereka akan membentuk sistem sekolah mereka sendiri (Kwee Tek-hoay 1969: 17-8).

Ketika pemerintah Belanda tidak memberikan reaksi atas pergerakan itu, THHK kemudian mendirikan sekolah mereka sendiri. Mereka mendirikan sekolah pertama dan lanjutan serta mendatangkan beberapa guru dan materi pendidikan langsung dari Cina (Kwee Tek-hoay 1969: 18; Purcell 1965: 435). Pada masa-masa awal, bahasa Belanda diajarkan sebagai salah satu mata pelajaran bahasa asing, namun karena biaya untuk mempekerjakan guru Belanda sangat mahal, mereka memutuskan untuk memilih bahasa Inggris. Guru-guru Cina yang mampu berbahasa Inggris banyak terdapat di Singapura, dan mempelajari bahasa Inggris menjadi jauh lebih berguna karena bahasa itu telah menjadi bahasa komersial Asia Timur. Seluruh sekolah yang dikelola THHK dijalankan dengan karakter nasiona-lisme Cina yang sangat kuat (Purcell 1965: 454). Hanya setelah bahasa Inggris dimasukkan ke dalam kurikulum, pemerintah Belanda akhirnya menyadari bahwa sekolah Belanda untuk orang-orang Cina sangatlah penting (Kwee Tek-hoay 1969: 18).

Pada akhirnya terbukti bahwa pendirian sekolah THHK mendapat dukungan dari komunitas Tionghoa di Indonesia. Itu telah menjadi inspirasi bagi munculnya sekolah-sekolah serupa di kota-kota lain di Indonesia. Pada 1911 badan-badan pendidikan dan cabang-cabang THHK di seluruh Hindia Belanda telah mencapai 93 cabang (Nio Joe Lan t.t.: 10). Pada 1907, lulusan sekolah-sekolah Cina tersebut memperolah beasiswa Cina dan meneruskan studi mereka di Cina (Nio Joe Lan t.t.: 101).

Pendirian sekolah-sekolah THHK menarik perhatian pemerintah kekaisaran di Cina yang kemudian mengirimkan seorang pejabat bernama Lauw Soe Kie dari Kanton ke Indonesia. Lauw mengunjungi beberapa sekolah Cina di Jawa. Pemerintah kekaisaran Cina mengutusnya ke Jawa dengan misi sebagai inspektur untuk sekolah-sekolah Cina di Indonesia. Ia disambut hangat oleh pejabat-pejabat THHK di berbagai tempat dengan upacara meriah (Kwee Tek-hoay 1969: 19; Willmott 1961: 5). Sebelum meninggalkan Jawa, ia menunjuk wakil untuk mengurus masalah pendidikan anak-anak Tionghoa di Indonesia, dan tak lama setelah itu pemerintah kekaisaran di Beijing menunjuk inspektur untuk mengontrol kualitas 
pendidikan di sekolah-sekolah Cina di seluruh Hindia Belanda (Willmott 1961: 5).

\section{Pembentukan Kamar Dagang}

Gagasan pembentukan kamar dagang muncul pada 1902 atas dorongan pemerintah kekaisaran Cina. Akibat dari anjuran tersebut beberapa pedagang terkemuka Tionghoa di Hindia Belanda membentuk serangkaian kamar dagang di beberapa kota besar. Organisasi itu diberi nama Tiong Hwa Siang Hwee, yang berarti "Asosiasi Perdagangan Cina". Di kemudian hari organisasi ini lebih dikenal dengan singkatannya yaitu Siang Hwee (Willmott 1960: 27). Fungsi utama dari Siang Hwee adalah sebagai asosiasi bisnis yang mempersatukan beragam aktivitas bisnis dan perdagangan di kalangan para pedagang Tionghoa. Organisasi ini juga berfungsi sebagai media untuk memecahkan masalah yang timbul di kalangan para pelaku bisnis Tionghoa pada waktu itu seperti pengaturan persaingan, pembatasan keanggotaan dalam bidang perdangangan tertentu dan masalah-masalah lain yang timbul sehubungan dengan interaksi bisnis di kalangan mereka (Heidhues 1974: 51).

Pada tahun-tahun berikutnya, peranan Siang Hwee sudah jauh melebihi fungsinya yang semula, yakni mengatur kegiatan bisnis. Kamar-kamar dagang ini didirikan dan diorganisasikan dengan didasarkan pada karakter nasionalisme Cina yang sangat kuat (Purcell 1965: 453). Pada perkembangannya kemudian ia berubah menjadi tulang punggung finansial bagi berbagai aktivitas komunitas Cina perantauan di Hindia Belanda. Kamar dagang juga berfungsi sebagai representasi bagi masyarakat Tionghoa pada saat melakukan perjanjian dengan pemerintah kolonial dalam urusan bisnis dan finansial. Selain itu, pada tahun-tahun berikutnya, Siang Hwee memainkan peranan penting dalam percaturan politik, berfungsi sebagai perwakilan dan juru bicara bagi orang-orang Tionghoa yang tinggal di luar Cina dengan pemerintah yang berkuasa di daratan Cina, baik pemerintah kekaisaran maupun republik. Setelah berdirinya Republik Cina, kepentingankepentingan mereka dilindungi dan ditulis dalam konstitusi (Heidhues 1974: 51). Siang Hwee kemudian menjadi penghubung utama antara masyarakat Tionghoa di luar Cina dengan pemerintah Cina di Cina daratan. Siang Hwee juga memegang peranan yang sangat krusial dalam membuat masyarakat Cina perantauan lebih condong kepada tanah airnya. Donald E. Willmott memberikan sebuah ilustrasi mengenai bagaimana Siang Hwee memainkan peranannya dalam membawa masyarakat Cina agar lebih dekat kepada Cina dengan mengambil kasus Siang Hwee cabang Semarang: 
Sianghwee Semarang didirikan pada tahun 1907. Bagaimana ia membantu meningkatkan kontak dengan Cina dan mempertinggi patriotisme Cina mungkin dapat terlihat dari beberapa aktivitasnya yang sangat banyak. Dalam periode selama sepuluh tahun antara tahun 1907 sampai 1917, badan ini telah mengumpulkan sumbangan yang besar dari anggota-anggotanya sebanyak sepuluh kali untuk bantuan bencana banjir di Cina dan enam kali untuk dukungan langsung bagi simpanan nasional Cina. Badan ini dalam periode yang sama juga membantu menjual surat-surat obligasi dan saham-saham pemerintah Cina kepada perusahaan-perusahaan swasta di Cina sebanyak lima belas kali. Pada tahun 1913 badan ini mendelegasikan direkturnya untuk menghadiri sebuah konferernsi di Peking yang bertujuan memilih sejumlah orang Cina perantauan untuk duduk dalam parlemen yang baru. Dalam beberapa kesempatan, Sianghwee meminta pemerintah Cina dengan mengatasnamakan masyarakat Cina lokal untuk menjadi penengah dalam berurusan dengan pemerintah kolonial Belanda... Sianghwee menjalankan semua fungsi konsulat, termasuk mengeluarkan paspor. Selain itu, di kantor pusat selalu tersedia semua edisi terakhir surat kabar dan majalah yang terbit di Cina (Willmott 1960: 27-8, mengutip Boekoe Peringatan 1907- 1937 Tiong Hwa Siang Hzvee [1937]).

Siang Hwee juga sangat aktif dalam mengembangkan pendidikan bagi anak-anak dan remaja kaum Tionghoa perantauan. Kamar dagang yang tersebar di kota-kota besar di Hindia Belanda telah menjadi tulang punggung finansial THHK (Williams 1960: 101).

\section{Aktivitas Politik}

Aktivitas politik Dr. Sun Yat-sen untuk menyebarkan nasionalisme Cina dan untuk membentuk republik di Cina bergema di setiap komunitas golongan Tionghoa yang tinggal di luar negeri. Dr Sun memulai aktivitas revolusionernya ketika ia berada di luar negeri. Oleh karena itu, tidaklah mengherankan jika kaum Tionghoa perantauan menjadi pendukung awal dari gerakan revolusionernya. Terbukti bahwa kaum Tionghoa yang ada di perantauanlah yang mengalami kontak awal dengan perkembangan sosial, politik dan ekonomi di luar Cina dan mereka pulalah yang mungkin menjadi orangorang Tionghoa pertama yang menyaksikan betapa mundurnya Cina pada masa itu. Oleh karena itu, ketika Dr. Sun Yat-sen mulai mengajarkan San Min Zhuyi (Tiga Asas Kerakyatan), ia dan gagasan-gagasannya disambut oleh sebagian besar anggota masyarakat Tionghoa di luar Cina.

Buku-buku, majalah dan selebaran merupakan alat yang sangat efektif untuk menyebarkan pemikiran revolusioner di kalangan orang Tionghoa perantauan. Tetapi kebanyakan dari orang-orang Tionghoa yang tinggal di luar negeri terdiri dari kaum buruh dan pekerja miskin. Mereka tidak mampu untuk membeli bahan bacaan. Untuk mengatasi hal itu, beberapa aktivis Cina 
terkemuka mengeluarkan gagasan untuk membentuk perkumpulan yang dinamakan Kamar Baca (Soe Po Sia). Asal mula perkumpulan Kamar Baca di Asia Tenggara mungkin meniru perkumpulan sejenis yang pertama kali didirikan oleh orang-orang Tionghoa di Singapura pada 1903. Pada awalnya perkumpulan membaca di Singapura dibentuk oleh orang-orang Tionghoa yang beragama Kristen dan bertujuan untuk menarik minat kaum muda Tionghoa pada agama Kristiani. Namun kemudian organisasi itu berkembang menjadi sebuah media untuk menumbuhkan kesadaran berkelompok dan bersemangat patriotik di kalangan orang-orang Tionghoa. Perkumpulan tersebut juga berkembang menjadi kelompok debat karena mereka sering mendatangkan pakar propaganda baik lokal maupun yang beraliran revolusioner untuk memberikan ceramah (Yen Ching Hwang 1976: 11). Dengan mundurnya aktivitas reformis di Cina dan di luar negeri, kaum revolusioner mengambil alih perkumpulan membaca Singapura. Melihat keberhasilan itu, Dr Sun lalu menyarankan para pemimpin revolusioner Cina setempat di wilayah Asia Tenggara lainnya untuk juga membentuk klub ruang baca itu (Yen Ching Hwang 1976: 112).

Perkumpulan Kamar Baca di Indonesia mulai muncul di beberapa kota pada 1908. Berbeda dengan perkumpulan pertama yang berdiri di Singapura, Soe Po Sia di Indonesia sejak semula didirikan untuk mendukung secara penuh usaha Dr. Sun Yat-sen di Cina. Pada tahun-tahun berikutnya, perkumpulan membaca di Hindia Belanda diorganisasikan untuk menjadi cabang lokal Kuomintang (Partai Nasionalis Cina) (Willmott 1960: 28). Dalam menjalankan aktivitasnya Soe Po Sia memiliki fungsi ganda, yaitu fungsi politik dan fungsi pendidikan. Menurut Png Poh-seng (1962: 215-6), kegiatan pendidikan sangatlah mencolok, sedangkan kegiatan politik dilaksanakan secara rahasia. Dengan cara itu perkumpulan membaca dapat melepaskan diri dari pengawasan ketat pemerintahan kolonial Belanda yang melarang semua kegiatan politik orang-orang Cina.

Salah satu dari aktivitas Soe Po Sia untuk menyebarkan pengaruhnya adalah dengan pempropagandakan kesadaran masyarakat Tionghoa untuk mencintai Cina dan memupuk perasaan bangga menjadi orang Cina. Usaha itu dilakukan dengan menerbitkan surat kabar. Pada masa pecahnya revolusi 1911 di Cina, asosiasi Soe Po Sia di Hindia telah menerbitkan 4 surat kabar. Di Batavia, cabang Soe Po Sia setempat menerbitkan Hoa Tok Po (Surat Kabar Cina). Surat kabar itu terbit dua kali seminggu dalam edisi Melayu dan Cina. Pada 1905, Soe Po Sia Semarang menerbitkan surat kabarnya sendiri dengan nama Djatwa Kong Po (Surat Kabar Umum Jawa). Soe Po Sia Surabaya 
menerbitkan Han Boen Sin (Harian Bahasa Cina Baru), sedangkan di Medan muncul Sumatra Po (Harian Sumatera) (Williams 1960: 108 -9).

Selain Soe Po Sia, juga terdapat beberapa gerakan nasionalis Cina radikal yang bersifat rahasia. Mereka kebanyakan aktif pada tahun-tahun sebelum dan sesudah revolusi 1911. Beberapa lembaga itu mengorganisasikan kaum buruh-buruh dan kaum muda. Organisasi-organisasi itu dianggap berbahaya oleh pemerintah kolonial dan pemimpin-pemimpin dari gerakan itu banyak yang dideportasi kembali ke Cina atau dipaksa meninggalkan Hindia Belanda (Willmott 1960: 28). Selain itu, terdapat berbagai asosiasi yang didirikan oleh orang-orang Cina perantauan dengan tujuan utama melakukan pengumpulan dana untuk membantu pemerintah Cina di Cina Daratan. Pada saat dikeluarkannya 21 Tuntutan Jepang yang terkenal pada 1915, masyarakat Cina di Hindia membentuk gerakan Dana Cinta Tanah Air untuk mengumpulkan uang sebagai bantuan keuangan bagi Cina dalam memperkuat dirinya ketika melawan Jepang (Willmott 1960: 28).

Dengan aktivitas itu, orang-orang Cina di Indonesia semakin bersatu karena ikatan-ikatan kebudayaan mereka dengan Cina dan kesadaran nasional mereka juga semakin kuat. Aktivitas mereka memiliki pengaruh yang sangat besar terhadap sikap pemerintah kolonial. Biro Urusan Cina (Kantoor voor Chineeze Zaken) yang didirikan pada 1900, setelah melihat aktivitas orang-orang Cina sebagai hasil dari gerakan nasionalisme Cina di Cina, menyarankan pemerintah kolonial untuk memperlunak sikapnya terhadap komunitas Cina di Hindia. Atas dasar saran dari Biro, maka pada 1910, peraturan yang memaksa orang-orang Cina untuk tinggal di wilayahwilayah tertentu dicabut (Purcell 1965: 349). Pemerintah juga membatalkan sistem surat jalan bagi orang-orang Cina. Itu merupakan perubahan yang sangat berarti bagi orang-orang Cina. Untuk pertama kalinya sejak kedatangan mereka di tanah jajahan, mereka diizinkan untuk bergerak kemana pun mereka suka seperti layaknya orang yang bebas.

\section{PERAN TOKOH-TOKOH REFORMIS DAN REVOLUSIONER CINA DI INDONESIA}

Seperti telah dijelaskan pada bagian awal tulisan ini, pengaruh para tokoh reformis dan revolusioner memainkan peranan yang sangat penting dalam kebangkitan nasionalisme dan semangat persatuan di antara orang-orang Cina perantauan di Indonesia. Namun bagaimanapun juga, peranan mereka secara langsung dalam proses kebangkitan sangatlah terbatas. Sebaliknya, tokoh-tokoh komunitas Cina setempatlah yang malahan memainkan peran penting. 
Pada 1903 Kang Youwei datang ke Jawa sebagai pelarian politik. Perjalanannya berkeliling Jawa dalam rangka mengunjungi sekolah-sekolah Cina yang dikelola THHK sudah diatur oleh cabang Batavia. Namun pengaruh Kang dalam pengembangan pendidikan Cina tidaklah terlalu besar, meskipun saat itu banyak terdapat guru dari sekolah THHK yang menjadi pengikut politik Kang. Sekolah-sekolah itu sudah berdiri jauh sebelum kedatangan Kang. Tampaknya, peran Kang dalam aktivitas orang-orang Cina di Indonesia terletak pada kenyataan bahwa ia dianggap sebagai tokoh politik yang misterius oleh pemerintah Belanda. Terdapat beberapa sumber yang menyatakan bahwa ia telah mengatur aksi boikot yang dilancarkan oleh para pedagang Cina dalam menghadapi perusahaan-perusahaan bisnis yang dijalankan oleh pemerintah kolonial. Ia juga dituduh telah menulis pamfletpamflet pada 1909 yang memprovokasi orang-orang Cina di Indonesia agar menolak tawaran kewarganegaraan Belanda (Williams 1960: 169).

Sun Yat-sen terlibat dalam aktivitas politik orang-orang Cina di Indonesia beberapa tahun setelah kemunculan Kang. Memang telah muncul banyak cabang Soe Po Sia dan Liga Revolusioner (Tong Meng Hui) juga telah berdiri di Batavia pada 1907, namun peranan Dr. Sun dalam aktivitas politik orangorang Cina di Indonesia tidaklah terlalu menentukan. Peranannya tidak lebih dari sekadar simbol. Pada 1908, ketika mengunjungi Singapura, ia mengajukan permohonan kepada Gubernur Jenderal Belanda di Batavia untuk berkunjung ke Hindia Belanda. Namun, Batavia menolak permohonan itu, tetapi kemudian muncul kabar angin di kalangan masyarakat Cina bahwa ia telah masuk ke Indonesia dengan nama samaran orang Jepang, Dr. Takano Choei (Williams 1960: 171). Aktivitas revolusionernya untuk menggulingkan pemerintahan Manzu (Qing) dan juga usahanya dalam mendirikan Republik Cina membuat ia menjadi sangat populer di kalangan orang-orang Cina di Indonesia. Akan tetapi ia tidak pernah memberi masukan bagi orang-orang Cina setempat dalam memecahkan problema setempat. Dalam menghadapi masalah setempat, terutama dalam hal-hal yang berhubungan dengan pemerintah kolonial, para pemimpin Cina lokal memainkan peran jauh lebih penting daripada para pemimpin politik revolusioner. Di sisi lain justru para pemimpin reformis dan pemimpin revolusionerlah yang memerlukan dukungan dari orang-orang Cina perantauan untuk menjalankan aktivitas mereka, terutama dalam bentuk bantuan keuangan. Peranan yang dijalankan oleh pemerintah Kekaisaran di Cina dalam membantu orang-orang Cina perantauan ketika menghadapi masalah di antara komunitas mereka sendiri atau pada saat mereka harus berhadapan dengan pemerintah kolonial, jauh 
lebih besar dibandingkan peranan tokoh-tokoh reformis maupun revolusioner di Cina.

\section{KESIMPULAN}

Sejak awal nasionalisme yang muncul di kalangan orang-orang Cina perantauan di Indonesia sangat dipengaruhi oleh perkembangan politik di Cina. Kecenderungan itu disebabkan oleh aktivitas politik, ekonomi, pendidikan dan sosial mereka yang sejak semula memang sangat berorientasi ke Cina. Ditambah lagi dengan adanya faktor-faktor lainnya seperti agama, rasial, kultural, ekonomi dan status sosial orang-orang Cina, tendensi itu juga menyebabkan kaum minoritas Cina di Indonesia menjadi sebuah kelompok yang sangat istimewa dalam masyarakat Indonesia. Faktor-faktor itu telah membuat masyrakat Cina menjadi suatu kelompok yang sangat eksklusif dalam aktivitas politik, ekonomi, sosial dan pendidikan di Hindia Belanda pada tahun-tahun berikutnya. Bahkan ketika nasionalisme di kalangan penduduk asli Indonesia mulai meningkat antara 1920-an dan 1930-an, orangorang Cina tetap memisahkan diri dari aktivitas politik penduduk asli Indonesia. Pendirian sekolah-sekolah Cina yang dipelopori oleh THHK dan terbentuknya kamar-kamar dagang menjadi faktor yang membuat perkembangan dalam masyarakat etnik Cina terpisah dari perkembangan di kalangan masyarakat lokal. Bahkan berdirinya THHK sebenarnya merupakan usaha untuk men-Totok-kan kembali masyarakat Peranakan. Baru pada tahun-tahun kemudian, ketika gelombang semangat nasionalisme di kalangan penduduk pribumi makin meninggi, khususnya sejak pertengahan dasawarsa 1930-an ada sebagian dari mereka yang mulai berorientasi dan kemudian bersimpati terhadap gerakan bangsa Indonesia untuk memperoleh kemerdekaan dari kaum kolonial Belanda.

\section{DAFTAR ACUAN}

Coppel, Charles A (1976), "Patterns of Chinese Political Activity in Indonesia," dalam J.A.C. Mackie (ed.), The Chinese in Indonesia. Honolulu: University Press of Hawaii.

Day, Clive (1966), The Dutch in Java. Kuala Lumpur: Oxford University Press.

Heidhues, Mary F. Somers (1974), Southeast Asin's Chinese Minorities. Rawburn (Vic), Longman. Houn, Franklin W. (1973), A Short History of Chinese Communism. Englewood Cliff, Prentice
Hall.

Kwee Tek-hoay (1969), The Origins of the Modern Chinese Movement in Indonesia (terj Lea E. Williams). Ithaca: Modern Indonesia Project Cornell University.

Nio Joe Lan (t.t.), Rizwajat 40 Taon dari Ting Hoa Hwee Koan, 1900 - 1939. Batavia.

Png Poh-seng (1962), "The Kuomintang in Malaya," dalam K.G. Tregonning, (ed.), Papers on Malayan History. Singapura: Journal of Southeast Asian History. 


\section{A. Dahana}

Purcell, Victor (1965), The Chinese in Southeast Asia. London: Oxford University Press.

Skinner, G. William (1967), "The Chinese Minority," dalam Ruth T. McVey (ed.), Indonesia. New Haven: HRAF Press.

Sun Yat-sen (t.t.), San Min Chu I. Taipei: China Publishing Co.

Suryadinata, Leo (1975), Pribumi Indonesians, the Chinese Minority, and China. Kuala Lumpur: Heinemann Educational Books (Asia).

Wang Gung Wu (1959), The History of the Nanyang Chinese. Singapura: Eastern Universities Press.

Williams, Lea E (1960), Overseas Chinese Nationalism: The Genesis of Pan-Chinese Movement in Indonesia 1900 - 1916. Glencoe, III: The Free Press.

Willmott, Donald E. (1960), The Chinese of Semarang. Ithaca: Cornell University Press. (1961), The National Status of the Chinese in Indonesia. Ithaca: Cornell University Press.

Yen Ching Hwang (1976), The Oversens Chinese and the 1911 Revolution. Kuala Lumpur: Oxford University Press. 